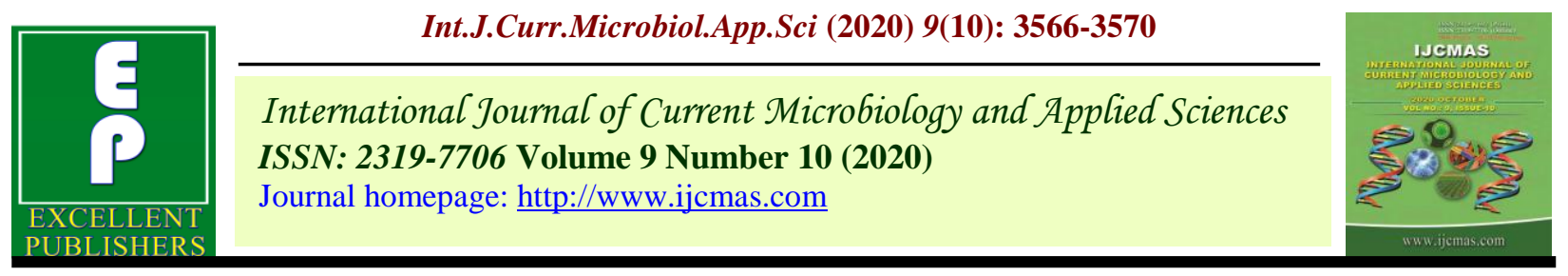

\title{
A Comparative Gender Study on Crop Production and Animal Management Activities in YSR Kadapa District of Andhra Pradesh, India
}

\author{
P. Laxmi Prasanna ${ }^{1^{*}}$ and B. P. Mohapatra ${ }^{2}$ \\ ${ }^{1}$ Department of Agriculture extension, Agriculture College, Bapatla, India \\ ${ }^{2}$ Department of Extension Education, College of Agriculture, Orissa University of Agriculture \\ and Technology, Bhubaneswar, Orissa, India \\ *Corresponding author
}

\section{A B S T R A C T}

\section{Keywords}

Farmer, Farm

women,

Community works,

Time utilization,

Participation

Article Info

Accepted:

26 September 2020

Available Online:

10 October 2020
The present study attempts to compare to farmer and farm women in crop production and animal management activities. The investigation was conducted in YSR Kadapa district of Andhra Pradesh. Research methodology was Expost-facto research design was selected to collection of data. Total 120 respondents selected from 10 randomly selected villages, out of 120 respondents 60 respondents were farmers, 60 respondents were farmwomen. Farmer and farm women were interviewed separately with pre structured interview schedule. Majority of farm women were middle aged, illiterates, landless labour, working as agriculture labour, falling under medium income level. Farmers were actively participated in purchase of inputs, purchase of animal, marketing and land leveling activities. Farm women were actively participated in weeding, irrigation, intercultural operation, fetching water for animal, cleaning animal, cleaning cattle shed, and collection of feed. Farm women role was very much neglected in financial activities.

\section{Introduction}

Indian economy mostly depends on agriculture. In rural India 80percent of population depend on agriculture directly and indirectly for their livelihood. As per Census 2011, the population of India is 1210.19 million comprising 586.47 million (48.5\%) females and 623.72 million (51.5\%) males. Females have a share of $48.1 \%$ in the urban population and of $48.6 \%$ in the rural. Farm women role in agriculture is significant and crucial. Farm women involvement and extend of participation vary from area to area and crop to crop. Farm women playing very important role in crop production, animal husbandry, dairy farming, poultry farming and horticulture. The role of women in agriculture sector is as important as men, therefore, women should educate themselves in agricultural. Majority of women is selfemployed and work in dangerous environments. Their daily tasks includes keeping and caring for the livestock at farms. They grow grains, cotton, fibers, fruit, and vegetables. The crop farmer plants, tills, fertilize, sprays, harvests, packs and stores the product. The livestock farmer feeds and cares 
for animals, while the horticulture farmers produce ornamental plants and nursery products. Livestock constitutes a major asset for many rural households and is a primary livelihood resource for many low-income rural communities (FAO, 2012a). Rural women represent about two-thirds of lowincome livestock keepers. They most likely own small stock (goats, sheep, pigs and poultry) and engage in dairy processing and marketing of milk and milk products, while men tend to own large stock (cattle, camels, horses) and "special" or new breeds (EADD, 2008). women's access to and control over resources and work burden is still not adequately addressed, despite ample evidence that better access for women tends to lead to higher agricultural yields and food and nutrition security. Women make an important contribution to family-run economic activities and represent an average of 43 percent of the agricultural workforce worldwide (FAO, 2011b). In this context to find out involvement of farm women in agriculture and animal management my investigation carried out with following objectives includes to study profile characteristics of farmer and farm women. To study different works performed by farmer and farm women in crop production. And also to study different works performed by farmer and farm women in animal management.

\section{Materials and Methods}

The ex-post facto survey research was conducted in Y.S.R.Kadapa district of Andhra Pradesh with a comparative sample of 60 farm women and 60 farmers. 5 mandal were selected randomly out of 31 mandal of Kadapa district. From each mandal two villages were selected randomly and proportionate Random sampling was applied for selection of respondents. The data were collected through personal interview by means of pre structured interview schedule.
Both farmer and farm women were separately interviewed for collecting first-hand information. Data so collected were statistically analyzed with the help of frequency, percentage and standard deviation. The results were separately interpreted to see the decision making pattern and activity profile in three series by male, female or by jointly in different activities like feeding, health care \& management and processing \& marketing. The responses have been tabulated, analysed and results are discussed in the fallowing sections.

\section{Results and Discussion}

\section{Profile characteristics of farmer and farm women}

The following table indicates the map of socio personnel characters of the respondents.

Table 1 reveals profile characteristics of farmer and farm women. Majority of farm women were middle aged, illiterates, landless labour, working as agriculture labour, falling under medium income level. In case of farmer, most of the respondents are middle aged, having illiterates fallowed by secondary educational qualification, medium farmers falling under medium income level. Farmers having more outward orientation (18.3) then compared with farm women (10).

\section{Different works performed by farmer and farm women in crop production}

Table 2 indicating different activities of crop production performed by farmer, farm women and combine by both farmer and farm women. The activities includes land preparation, seed selection, inputs purchasing, manures and manuring, sowing, weeding, irrigation, intercultural operations, harvesting, packing, transportation, marketing of products. The results clearly depicting that 
more number of farmers were actively participated in inputs purchasing (80.8), marketing of products (72.5), land preparation (69.1), seed selection (65.8) followed by packing (56.6) and transportation (54.1). Very less number of farmers were actively participated in harvesting (5.8), weeding (8.33), intercultural operations (10.0) and irrigation (20.0). Majority of farm women were actively participated in weeding (87.5), intercultural operation (80.3) and irrigation (65.0). Very less number of farm women were actively participated in input purchasing (6.66), land preparation (7.5), and seed selection (10.8). Farmer and farm women combine actively participated in harvesting
(81.6) and manure and mannuring (48.3.). The results are clearly showing that majority of farmers were actively participated in financial activities like input purchasing marketing of products and very less participation on crop production activites like weeding, irrigation and intercultural operation. Both farmer and farm women actively participated in manure and mannuring, very less participation on intercultural operation. There is a need to educate and empower both farmer and farm women to equal distribution of resources and work distribution among themselves to get optimum profit of crop production.

Table.1 Socio personnel profile of the respondents

\begin{tabular}{|c|c|c|c|c|}
\hline S.No & Variables & Categories & $\begin{array}{c}\text { Farmer } \\
\text { Frequency }(\%)\end{array}$ & $\begin{array}{l}\text { Farm Women } \\
\text { Frequency }(\%)\end{array}$ \\
\hline \multirow[t]{3}{*}{1} & \multirow[t]{3}{*}{ Age } & Young age(up to 25 years) & $13(21.6)$ & $7(11)$ \\
\hline & & Middle age(up to 50 years & $30(50)$ & $40(66.6)$ \\
\hline & & Old age(above 50 years) & $17(28.3)$ & $13(21.6)$ \\
\hline \multirow[t]{5}{*}{2} & \multirow{5}{*}{$\begin{array}{l}\text { Level of } \\
\text { education }\end{array}$} & Illiterate & $25(41.6)$ & $41(68.3)$ \\
\hline & & Primary education & $13(21.6)$ & $4(6.6)$ \\
\hline & & Secondary education & $18(30)$ & $15(25)$ \\
\hline & & Graduation & $3(5)$ & $0(0)$ \\
\hline & & Post graduation & $1(1.6)$ & $0(0)$ \\
\hline \multirow[t]{4}{*}{3} & \multirow{4}{*}{$\begin{array}{l}\text { Income per } \\
\text { month }\end{array}$} & Below poverty line & $17(28.3)$ & $12(20)$ \\
\hline & & Low income level & $10(16.6)$ & $19(31.6)$ \\
\hline & & Medium income level & $29(48.3)$ & $22(36.6)$ \\
\hline & & High income level & $4(6.6)$ & $7(11.6)$ \\
\hline \multirow[t]{5}{*}{4} & \multirow{5}{*}{$\begin{array}{l}\text { Farm } \\
\text { category }\end{array}$} & Landless labour & $9(15)$ & $26(43.3)$ \\
\hline & & Marginal farmer & $3(5)$ & $14(23.3)$ \\
\hline & & Small farmer & $21(35)$ & $7(11.6)$ \\
\hline & & Medium farmer & $23(38.3)$ & $12(20)$ \\
\hline & & Large farmer & $4(6.6)$ & $1(1.6)$ \\
\hline \multirow[t]{3}{*}{5} & \multirow{3}{*}{$\begin{array}{l}\text { Family } \\
\text { occupation }\end{array}$} & Farmer & $31(51.6)$ & $12(20)$ \\
\hline & & Agri. Labour & $25(41.6)$ & $38(63.3)$ \\
\hline & & Any other & $4(6.6)$ & $10(16.6)$ \\
\hline \multirow[t]{2}{*}{6} & \multirow{2}{*}{$\begin{array}{l}\text { Outward } \\
\text { orientation }\end{array}$} & Localite & $49(81.6)$ & $54(90)$ \\
\hline & & cosmopolite & 11(18.3) & $6(10)$ \\
\hline
\end{tabular}


Table.2 Different Crop Management activities performed by farmers, farm women and farmer and farm women

\begin{tabular}{|l|l|c|c|c|}
\hline S.N & Activity & FARMER (\%) & FARM WOMEN (\%) & JOINTLY (\%) \\
\hline $\mathbf{1}$ & $\begin{array}{l}\text { Land } \\
\text { Preparation }\end{array}$ & 69.1 & 7.5 & 25.8 \\
\hline $\mathbf{2}$ & Seed selection & 65.8 & 10.8 & 23.3 \\
\hline $\mathbf{3}$ & $\begin{array}{l}\text { Inputs } \\
\text { purchasing }\end{array}$ & 80.8 & 6.66 & 12.5 \\
\hline $\mathbf{4}$ & $\begin{array}{l}\text { Manures and } \\
\text { Manuring }\end{array}$ & 25.0 & 23.3 & 48.3 \\
\hline $\mathbf{5}$ & Sowing & 41.6 & 33.3 & 25.0 \\
\hline $\mathbf{6}$ & Weeding & 8.33 & 87.5 & 4.16 \\
\hline $\mathbf{7}$ & Irrigation & 20.0 & 65.0 & 15.0 \\
\hline $\mathbf{8}$ & $\begin{array}{l}\text { Intercultural } \\
\text { operations }\end{array}$ & 10.0 & 80.3 & 9.1 \\
\hline $\mathbf{9}$ & Harvesting & 5.8 & 12.5 & 81.6 \\
\hline $\mathbf{1 0}$ & Packing & 56.6 & 17.5 & 25.8 \\
\hline $\mathbf{1 1}$ & Transportation & 54.1 & 10.0 & 11.6 \\
\hline $\mathbf{1 2}$ & $\begin{array}{l}\text { Marketing of } \\
\text { products }\end{array}$ & 72.5 & 15.8 & \\
\hline
\end{tabular}

Table.3 Different animal management activities performed by farmers, farm women and combine by farmer and farm women

\begin{tabular}{|c|c|c|c|c|}
\hline S.N & Activity & FARMER $(\%)$ & FARMWOMEN (\%) & JOINTLY (\%) \\
\hline & Purchase of animals & 92.5 & 3.3 & 4.16 \\
\hline & Cleaning cattle shed & 7.5 & 80.8 & 11.6 \\
\hline & Cleaning the animal & 10.0 & 84.1 & 5.8 \\
\hline & Fetching water for animal & 1.6 & 93.3 & 5.0 \\
\hline & Collecting fodder for animals & 5.0 & 74.1 & 20.8 \\
\hline & Preparation of cattle feed & 12.5 & 71.6 & 15.8 \\
\hline & Feeding the animal & 5.8 & 63.3 & 30.8 \\
\hline & Milking & 7.5 & 78.3 & 14.1 \\
\hline & Making curd, butter and ghee & 12.5 & 75.8 & 11.6 \\
\hline & $\begin{array}{l}\text { Marketing milk and milk } \\
\text { produce }\end{array}$ & 67.5 & 24.1 & 8.3 \\
\hline & Taking care of sick animal & 45.5 & 24.1 & 28.3 \\
\hline
\end{tabular}

Different works performed by farmer and farm women in animal management

Table 3 reveals different animal management activities performed by farmers, farm women and combines by farmer and farm women.
The activities include purchase of animals, cleaning cattle shed, cleaning the animal, fetching water for animal, collecting fodder for animals, preparation of cattle feed, feeding the animal, milking, making curd, butter and ghee, marketing milk and milk produce and 
taking care of sick animals. Majority of farmer were participated in purchase of animals (92.5), marketing milk and milk produce (67.5), taking care of sick animal (45.5) very less farmers were participated in fetching water for animal (1.6), collection fodder for animal (5.0) feeding the animal (5.8) milking (7.5) majority of farm women were participated in fetching water for animal (93.3), cleaning the animal (84.1), and milking (80.8). Farm women participation were very negligible in purchase of animals (3.3). The results depicting that farmers role was very dominated in financial activities like purchase of animal and marketing of products, farm women actively participated in majority of animal management works like fetching of water, cleaning animals, cattle shed, collecting feed and protecting animal still farmwomen role was very much negligible in financial activities.

The study was concluded that majority of farmers were participated in purchase of inputs, purchase of animal, marketing of products and land leveling. Farmer's role in financial activites was much dominated. Majority of farm women were participated in weeding, irrigation, intercultural operations in crop production, fetching water, cleaning, feeding protecting in animal management. Farm women role was negligible in financial and marketing aspects. There is a need to empower and educate farmer and farm women to get equal access to available resources for equal distribution and sustainable and steady successful growth.

\section{References}

EADD (East Africa Dairy Development). 2008. East Africa Dairy Development Project. Nairobi, EADD and International Livestock Research Institute.

FAO. 2011a. The role of women in agriculture. ESA Working Paper No. 11-02, prepared by the SOFA Team and Cheryl Doss. Rome.

FAO. 2012a. Gender: Projects. Accessed 28 July 2014 (available at http://www.fao.org/ gender/genderhome/gender-projects/genderprojectsdet/en/c/158380/).

\section{How to cite this article:}

Laxmi Prasanna, P. and Mohapatra, B. P. 2020. A Comparative Gender Study on Crop Production and Animal Management Activities in YSR Kadapa District of Andhra Pradesh, India. Int.J.Curr.Microbiol.App.Sci. 9(10): 3566-3570.

doi: https://doi.org/10.20546/ijcmas.2020.910.411 